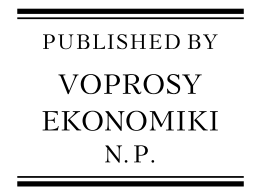

\title{
Structural changes and economic growth in the world economy and Russia
}

\author{
Valery Mironov*, Liudmila Konovalova \\ National Research University Higher School of Economics, Moscow, Russia
}

\begin{abstract}
The article considers the problem of the relationship of structural changes and economic growth in the global economy and Russia in the framework of different methodological approaches. At the same time, the paper provides the analysis of complementarity of economic policy types, which, on the one hand, are aimed at developing the fundamentals of GDP growth (institutions, human capital and macroeconomic stabilization), and on the other hand, at initiating growth (with stable fundamentals) with the help of structural policy measures. In the study of structural changes in the global economy, new forms of policies of this kind have been revealed, in particular aimed at identifying sectors - drivers of economic growth based on a portfolio approach. In a given paper a preliminary version of the model of the Russian economy is provided, using a multisector version of the Thirlwall's Law. Besides, the authors highlight a number of target parameters of indicators of competitiveness of the sectors of the Russian economy that allow us to expect its growth rate to accelerate above the exogenously given growth rate of the world economy.
\end{abstract}

Keywords: economic growth, labour productivity, structure of economy, structural policy, Thirlwall's law, Russia.

JEL classification: O10, O11, O14, O40, O50, P52.

\section{Introduction}

The structural distortions caused by the predominance of the energy and commodity sectors, without the appropriate development of high-tech manufacturing and a service sector, remain a vital trait of the Russian economy. Its annual growth rates have not exceeded $1 \%$ during the past decade. In our opinion, the structural heterogeneity of the Russian economy is a factor in both the practical activities of the regulators and in the choice of the conceptual framework for elaborating economic development strategies and tactics. At the same time,

\footnotetext{
* Corresponding author, E-mail address: vmironov@hse.ru
} 
there is growing interest in the structuralist approaches to economic analysis, which many experts believe to be not so much an alternative to mainstream concepts as a complement to them.

It was noted in the literature (Rodrik, 2013a; McMillan et al., 2017) that in many countries focused primarily on structural policy (neglecting the development of institutions and other fundamentals) economic growth has usually been unstable, though quite rapid at certain times (in particular, in Vietnam). Countries that focused only on the fundamentals of long-term growth (investments in human capital, developing market institutions and infrastructure) and on macroeconomic stabilization succeeded in a number of areas, but failed to achieve high growth rates (some Latin American states). South Korea, Singapore, Hong Kong (and previously Japan) managed to achieve the balance between developing fundamentals and ensuring macroeconomic stabilization, on the one hand, and structural policy, on the other. There are few examples of successful catch-up development.

In this article, we conduct an analysis of the structuralist methodology, certain trends in the world economic structure during the past few decades, as well as their influence on specific forms of structural policy geared towards initiating economic growth. In particular, we describe approaches to forecasting and devising economic policy related to identification of sectors based on portfolio (multisectoral) concepts that escalate economic growth. The forecast is based on the sectoral structure of the economy, while the Kaldor-Thirlwall model, in its multisectoral version, becomes the basis for an open economy. In the process of development of a tentative version of this model for the Russian economy, we demonstrate that certain important economic policy aims can be elaborated via modern structuralist approaches.

\section{The correlation between structural changes and economic growth}

Although structuralism gained popularity in economic science during the 1940s, its roots can be found in earlier periods of development of numerous sciences, e.g., psychology, philosophy, anthropology (Palma, 1987; Blankenburg et al., 2008). Over time, structuralism became an independent theoretical approach, which could be regarded as a method for theorizing alternatives to traditional economic methods. While the mainstream theory, represented mainly by the neoclassical approach, is deductive and expressed in terms of the economy's "homogeneity," the structural approach and an analysis of structural changes in the economy assume that the interdependent components of the economic system comprise a complex unit and include system peculiarities that do not allow for their study by analyzing individual components (Jackson, 2003).

The structuralist approach usually stresses that economic development is closely associated with a radical transformation of the production structure to initiate economic growth, remove bottlenecks and other factors responsible for the slow-paced development, ensure the reallocation of resources to sectors of the economy (engines of growth, or growth escalators) that are characterized, in particular, by a more pronounced increase in economies of scale compared with other sectors and positive externalities. Structuralists focus on problems associated with dualism in the domestic economy and international trade, with 
interdependent sectors, poverty traps, technological inequality, and balance-ofpayment constraints.

Unlike the structural approach, the traditional equilibrium concepts of balanced growth are based mainly on the rate of savings and capital accumulation, often using a single production function for the entire economy, and treating industry (sectoral) changes just as side-effects of economic growth and an increase in GDP per capita (McMillan and Rodrik, 2011). As noted in the structuralist literature, the traditional neoclassical approach with emphasis on supply (see, e.g. Solow, 1956; Swan, 1956; Uzawa, 1961), which describes modern economic growth essentially as sustainable improvements in productivity and the standard of living (according to Kuznets, 1973), is not always able-due to the peculiarities of its methodology - to take into account the potential correlation between changes in the economic structure and economic growth, or to account for the lack of convergence in development levels between countries.

In the structuralists' opinion, the modern theories of endogenous growth better incorporate the specifics of economic activity as a growth factor. These new theories include endogenous characteristics of economic development and technical progress in the analysis, and place special emphasis on enhancing certain areas of economic activity (e.g., R\&D or human capital reproduction), whereas specific features of particular sectors are still ignored by endogenous growth theories (although post-Keynesian structuralists attach great importance to them). The latter either highlights the role of demand, even in the long-run perspective (see, e.g., Setterfield, 2011; Thirlwall, 2013; Ocampo et al., 2009), or suggests that demand and supply be studied concurrently, as parts of a multisectoral economic structure (see Baranzini and Scazzieri, 1990).

Below, we interpret sectoral changes narrowly, though not only as a "reallocation of economic activity across three broad sectors (agriculture, manufacturing, and services) that accompanies the process of modern economic growth" (Herrendorf et al., 2014, p. 857), but, generally, as a change in the proportion of economic sectors in total output or employment, taking into account that modern databases, e.g., socioeconomic statistics in the WIOD database (SEA WIOD 2016 database - see Timmer et al., 2015a), enable us to use data from over 50 sectors of the economy. The matter of the influence of structural changes in a broad sense (taking into account the development of the financial sector, demographic processes, urbanization, migration, etc.) on economic growth has been studied, in particular, in Greenwood and Seshadri (2005), and Acemoglu (2009, pp. 725-771), but it will not be addressed in this paper.

For a long time, economists have noted the generally positive correlation between the intensity of structural (sectoral) shifts and economic growth rates. This is also specific to the past few decades. ${ }^{1}$ Of course, the correlation is not absolute, and the intensity of structural changes may either be the consequence of, or the reason for, economic growth. It should be noted that in modern traditional theory, "there exists no general theory of structural change, but there exist a variety of theoretical approaches that are concerned with the explanation of structural shifts between the three broad sectors of the private economy [primary, secondary and tertiary] and among the industries within these sectors" (Kruger, 2008, p. 331).

1 This is shown for 108 countries between 1995 and 2011, in UNIDO (2016, pp. 27-28). 
Kuznets regarded structural changes as one of the six specific traits of modern economic growth. In particular, he wrote that "rapid changes in production structure are inevitable - given the differential impact of technological innovations on the several production sectors, the differing income elasticity of domestic demand for various consumer goods, and the changing comparative advantage in foreign trade" (Kuznets, 1973, p. 250).

As demonstrated by empirical studies, there are two main types of structural changes in the global economy (Romano and Trau, 2017): intersectoral structural shifts, as in the three-sector economy concept by Fisher-Clark-Fourastié (Fisher, 1939; Clark, 1957), and intrasectoral shifts that cause a consistent change in the states of specialization and production diversification, as in Imbs and Wacziarg (2003), and Imbs et al. (2014). The analysis of these changes clearly demonstrates differences between the traditional and the structuralist approaches: the latter, which recognizes the importance (at least at a certain stage of a country's development) of diversifying the composition of the sectoral portfolio, stays in evident contradiction with the findings of neoclassical theory, which, ever since D. Ricardo, has accentuated specialization as the main trend in developing foreign trade connections.

In contrast to the traditionalists, as part of modern structuralist concepts (the "new structural economics" based on neoclassical approaches, and neo-Kaldorian approaches within neo-Keynesianism), close to development economics but not coinciding with it, structural changes are regarded as one of the sources of economic growth rather than a consequence of it (Lin, 2011). It is highlighted that "economic miracles," i.e. rapid (at 4.5\% annual rate per capita) and sustainable (at least 30 years) growth, ${ }^{2}$ have been observed exactly against the background of clearly manifested structural changes.

As noted in the literature, the rudiments of the structural approach are visible in the works of A. Smith and D. Ricardo, who treated the division of labor and the modernization of the production system (by substituting land as a limited and non-renewable resource with the resources produced) as factors of structural changes (Silva and Teixeira, 2008). Studying the similar process of substituting non-digital assets with digital assets enabled a number of authors (Aghion et al., 2017; Nordhaus, 2015) to model (effectively based on structuralist approaches) scenarios for the effects of structural shifts on economic growth under a new technology revolution and the development of artificial intelligence.

At the same time, there is no strong antagonism between economic structuralism and the mainstream. Of late, economic regulators in developing countries have increasingly treated the analysis of changes in the sectoral composition of the economy and structural policy as additions to economic growth analysis (based on the Solow model and endogenous growth). Bearing in mind that in a great number of cases economic growth accelerated due to stable fundamentals, and irrespectively of the phase of the economic cycle, many economists began to distinguish between economic policy factors initiating growth, on the one hand, and factors maintaining growth, on the other, or factors of "proximate and ultimate causality" (Maddison, 1991, ch. 1; Rodrik, 2003; Szirmai, 2012). Significant factors that

\footnotetext{
2 Since 1950, around 24 cases and 4 clusters of such countries have been identified: European, Asian, African, and Middle Eastern (Rodrik, 2013b).
} 
initiate growth include certain structural changes and the structural policy that facilitates them, while factors making growth sustainable in the long run are: macroeconomic stabilization, development of industrial and financial infrastructure, institutions, and human capital.

Notably, the advocates of the concept of a new structural economy based on neoclassical theoretical principles do not consider it necessary to use all available (including dirigiste) means to enforce the diversification of the industry portfolio to mitigate development risks or to support sectors possessing positive externalities for the economy as a whole. Diversification in this case is often regarded not so much as a main goal, but more as a consequence of economic growth and of the structural changes initiating it (Newfarmer et al., 2009), which are caused by "creative destruction" processes stimulated by governments using modern structural policy tools (usually non-dirigiste).

\section{The impact of structural shifts on changes in the forms of structural policy in the global economy in recent decades}

The most important traits (trends) of structural changes in the global economy include the following. First, the change in the direction of productivity growth across the economy (actual economic growth), which may be primarily caused either by the reallocation of labor from low-productivity sectors to highproductivity ones, or by higher labor productivity within sectors. In the former case (where the "between" effect prevails), the important factor is the economic policy measures driving the increase in labor and production factors mobility, the lowering of bureaucratic and administrative barriers, the adaptation of rural citizens to urban life, etc. In the latter case (where the "within" effect is predominant), there is a need for measures encouraging technical progress within sectors, which implies emphasis on developing innovative national and sectoral systems, the accelerated integration of companies operating in certain sectors into global value chains, on identifying and stimulating the development of sectors driving economic growth, and promoting the so-called unconditional convergence (Rodrik, 2013c).

Second, the transformation of the role of individual sectors in the global economy can also be defined as structural change. Analyzing this process provides an answer to the question of whether deindustrialization and the transition to a more prevalent services sector are taking place. Third, in setting priorities for structural policy, we believe it is important to answer the question: what stylized facts are associated with identifying the macroeconomic factors and vectors of economic growth (increasing investments, exports, etc.), increasing the chances of success for a given structural policy and corresponding to well-known cases of rapid and lengthy accelerations in economic growth (often unexpected)? What we are speaking about are the "economic miracles," or autonomous accelerations of economic growth, as we suggest calling them, by analogy with autonomous recessions, when a crisis in a given country is not connected with recession in the global economy or in a macro region where that country is located (Mironov and Kanofyev, 2014).

With respect to the first trend, we note that the significant role of structural shifts in increasing labor productivity and economic growth rates has been proven empirically and explained conceptually (Lewis, 1954; Clark, 1957; Lin, 2011). 
What we mean is that the reallocation of excess workforce from agriculture to the modern industrial sector improves labor productivity in the economy as a whole. However, structural changes do not always encourage growth acceleration, as labor may move from sectors with higher and faster-growing productivity, to sectors with lower and stagnant productivity, leading to lower productivity growth rates across the economy (Baumol, 1967). Cases where labor reallocation detracts from economic growth are confirmed by empirical evidence for certain groups of developing countries in McMillan et al. (2014), De Vries et al. (2015), and, with respect to manufacturing industries, for a sample of 39 countries from 1973 to 1990, in Fagerberg (2000).

Our calculations of the "between" and "within" effects for 43 developed and developing countries from 1970 to 2010 (divided into two subperiods) have demonstrated that, despite the wide labor productivity gaps between industries after 1990, the contribution of labor reallocation between sectors to the increase in total productivity remained persistently low and generally dropped sharply in developing countries (Table 1). ${ }^{3}$ This means that, in terms of structural policy, developing countries bring measures stimulating growth at the sectoral level and a search for industries driving growth to the foreground, rather than measures to improve the efficiency of reallocating resources between sectors (although reallocation is still relevant for some countries).

We now proceed to the analysis of the second trend of structural changes in the global economy. When using the indicator of value added in current prices, the stylized facts of shifts in sectoral composition in developed countries in recent decades indicate a sharp decline in the share of agriculture and manufacturing, as well as an evident growth in the services sector (Fig. 1). However, these trends disappear when the same data are expressed in constant prices: the contribution from the manufacturing industry as a whole has been generally stable since the 1970s (with a decline over the past decade which would be premature to call a sustainable trend), and the share of the services sectors, while having grown from $60 \%$ to $70 \%$ since the 1970 s, has done it less evidently than if the data are expressed in current prices (see Fig. 1).

The general picture of changes in the sectoral composition of developing countries is largely similar to the one observed in developed countries (see Fig. 1). However, there are indications in the literature that this group is quite heterogeneous within itself. In many developing countries today, the proportion of GDP from manufacturing is lower than before the most recent wave of globalization, even if we express the indicator in constant prices. At the same time, the manufacturing sector achieved peaks both in terms of value added and the employment rate, and with a lower per capita GDP than between the 1930s and the $1980 \mathrm{s.}^{4}$ The decreasing share of the manufacturing industry in the GDP

\footnotetext{
3 In aggregate (as a sum), the "between" and "within" effects presented in Table 1 equal 1, so that annual average labor productivity growth for the period can be broken down into contributions made by each effect, which may be either positive or negative. We use shift-share analysis (SSA) to calculate the "between" and "within" effects, as in McMillan and Rodrik (2011). A detailed description of the methods used for decomposing labor productivity dynamics into the "between," "within" and other effects. (SSA-analysis) see in particular in Voskoboynikov and Gimpelson (2015).

4 Usually there is a correlation in the shape of the "hump" here: as per capita GDP grows, the proportion of GDP from manufacturing rises, peaks, and declines.
} 
Table 1

Contribution to labor productivity growth across the economy made by labor productivity growth in individual industries ("within" effect) and labor reallocation between industries ("between" effect) in developed and developing countries between 1970 and 2010.

\begin{tabular}{|c|c|c|c|c|c|c|c|c|}
\hline \multirow[t]{2}{*}{ Country } & \multicolumn{2}{|c|}{$\begin{array}{l}\text { Labor } \\
\text { productivity, } \\
\text { USD by } \\
\text { PPP-2011 }\end{array}$} & \multicolumn{2}{|c|}{$\begin{array}{l}\text { Annual } \\
\text { average labor } \\
\text { productivity } \\
\text { growth, \% }\end{array}$} & \multicolumn{2}{|c|}{$\begin{array}{l}\text { Contribution } \\
\text { of "between" } \\
\text { effect to labor } \\
\text { productivity } \\
\text { growth }\end{array}$} & \multicolumn{2}{|c|}{$\begin{array}{l}\text { Contribution } \\
\text { of "within" } \\
\text { effect to labor } \\
\text { productivity } \\
\text { growth }\end{array}$} \\
\hline & 1970 & 2010 & $\begin{array}{l}1970- \\
1989\end{array}$ & $\begin{array}{l}1990- \\
2010\end{array}$ & $\begin{array}{l}1970- \\
1989\end{array}$ & $\begin{array}{l}1990- \\
2010\end{array}$ & $\begin{array}{l}1970- \\
1989\end{array}$ & $\begin{array}{l}1990- \\
2010\end{array}$ \\
\hline \multicolumn{9}{|l|}{ Developed countries } \\
\hline USA & 54.9 & 112.3 & 1.26 & 2.31 & 0.19 & -0.03 & 0.81 & 1.03 \\
\hline United Kingdom & 25.2 & 54.1 & 1.87 & 1.96 & -0.26 & -0.22 & 1.26 & 1.22 \\
\hline Japan & 21.3 & 66.5 & 3.65 & 1.89 & 0.09 & 0.04 & 0.91 & 0.96 \\
\hline $\begin{array}{l}\text { France }(+5 \text { other } \\
\text { countries })\end{array}$ & 28.0 & 59.0 & 2.05 & 1.63 & -0.02 & -0.15 & 1.02 & 1.15 \\
\hline \multicolumn{9}{|l|}{ Asian countries (except } \\
\hline \multicolumn{9}{|l|}{ Japan) } \\
\hline Singapore & 17.8 & 91.7 & 3.42 & 4.76 & 0.17 & 0.05 & 0.83 & 0.95 \\
\hline South Korea & 7.0 & 47.9 & 6.10 & 3.50 & 0.21 & -0.03 & 0.79 & 1.03 \\
\hline China & 3.0 & 15.5 & 2.23 & 7.07 & 0.90 & 0.13 & 0.10 & 0.87 \\
\hline India ( +6 other countries) & 3.4 & 10.3 & -0.64 & 6.24 & -0.53 & 0.17 & 1.53 & 0.83 \\
\hline \multicolumn{9}{|l|}{ Latin America } \\
\hline Venezuela & 20.0 & 37.5 & -0.31 & 3.63 & -3.77 & 0.10 & 4.77 & 0.90 \\
\hline Mexico (+2 other) & 28.6 & 29.3 & -0.63 & 0.62 & -1.02 & 0.39 & 2.02 & 0.61 \\
\hline \multicolumn{9}{|l|}{ Africa } \\
\hline Botswana & 3.8 & 35.4 & 7.74 & 4.04 & 0.49 & -0.12 & 0.51 & 1.12 \\
\hline South Africa & 20.2 & 33.0 & 0.79 & 1.81 & 1.17 & -0.11 & -0.17 & 1.11 \\
\hline $\begin{array}{l}\text { Ethiopia } \\
\qquad(+8 \text { other countries })\end{array}$ & 1.9 & 2.0 & 0.01 & 0.16 & -9.86 & 5.05 & 10.86 & -4.05 \\
\hline \multicolumn{9}{|l|}{ Arithmetic mean } \\
\hline All 39 countries & 17.0 & 37.4 & 1.33 & 2.49 & 0.45 & -0.13 & 0.55 & 1.13 \\
\hline Developed countries & 29.7 & 64.9 & 1.92 & 2.03 & -0.06 & -0.16 & 1.06 & 1.16 \\
\hline Developing countries & 11.3 & 27.1 & 1.10 & 2.66 & 0.64 & -0.11 & 0.36 & 1.11 \\
\hline Asia & 8.1 & 40.2 & 2.92 & 3.96 & 0.18 & -1.53 & 0.82 & 2.53 \\
\hline Latin America & 22.7 & 30.1 & -0.11 & 1.50 & 4.13 & 0.02 & -3.13 & 0.98 \\
\hline Africa & 7.2 & 10.9 & -0.24 & 1.87 & -0.79 & 1.38 & 1.79 & -0.38 \\
\hline
\end{tabular}

Note: PPP-2011 refers to purchasing power parity in terms of 2011 prices. Labor productivity is calculated as the quotient of value added (VA), expressed in USD, PPP, by the employment rate in the economy.

Source: Authors' calculations based on GGDC database, data for 39 countries and 10 sectors (Timmer et al., 2015b).

for those developing countries can be attributed to specific temporary factors (e.g., to the explosive growth of the Chinese economy, with its high share of manufacturing output); this is not a systematic or long-term trend (UNIDO, 2016). This phenomenon was called premature, or early, deindustrialization, i.e. when the manufacturing industry is replaced with low-productivity service sectors, often with a high share of unofficial employment as in Africa during recent decades (Rodrik, 2015; McMillan et al., 2017). Premature de-industrialization should be distinguished from natural (endogenous) (mature deindustrialization), when manufacturing gives way to technologically advanced, dynamic service sectors with high labor productivity. 
(a) In current prices
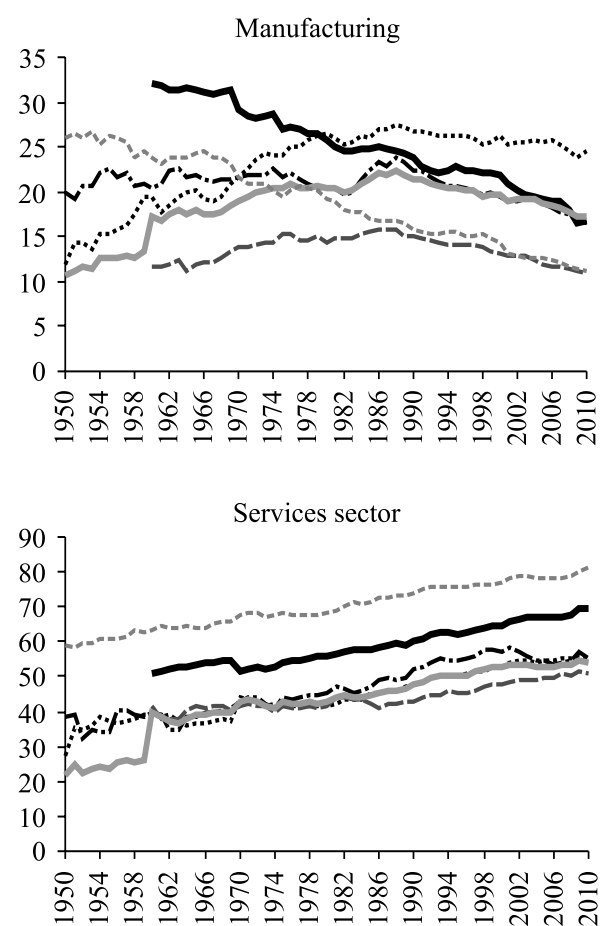

(b) In constant (2005) prices
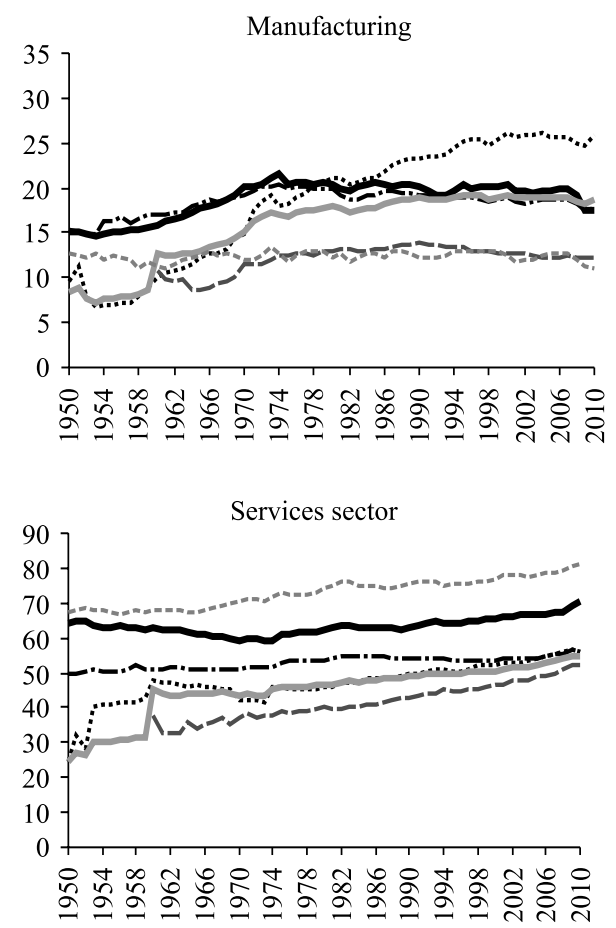

\begin{tabular}{|c|c|c|}
\hline $\begin{array}{l}\cdots \cdots \cdot \text { Asia } \\
--- \text { Africa }\end{array}$ & $\begin{array}{l}\text { - - Latin America } \\
\text { - }\end{array}$ & $\begin{array}{l}\text { Developed countries } \\
\text { Developing countries }\end{array}$ \\
\hline
\end{tabular}

Fig. 1. Economic structure of major developed and developing countries (share of sectors in gross value added in current and constant prices, \%).

Note: The list of countries and data by year can be found on the University of Groningen website (https://www.rug. $\mathrm{nl} /$ ggdc/productivity/10-sector/). The services sectors include commerce, restaurants and hotels, transportation, storage and communications, finance, insurance, real estate and business services, public and social services. Source: Authors' calculations based on GGDC database (Timmer et al., 2015b).

The "servicization" of the world economy (the increasing share of the services sector) is happening against the background of a diminishing proportion of agriculture, with manufacturing maintaining a relatively stable share. According to available estimates, it is not falling within the global economy in either constant or current prices if the value added indicator is used (Felipe and Mehta, 2016; Haraguchi et al., 2017). This is attributable to a large extent to the rapid growth of the Chinese economy, although the proportion of GDP from manufacturing is declining in the majority of other countries. We see this as an important fact in explaining the causes of reindustrialization and reshoring brought about by scientific and technological progress in the developed and most competitive developing economies (Kondratiev, 2017).

Our next stop is the third question concerning trends in the structural shifts of the global economy connected with the stylized facts of changes that stimulate autonomous economic acceleration in particular countries. There are observations in the structuralist literature that economic growth is accompanied by changes in a number of variables, i.e. technological modernization, accumulation of human 
capital and investments in fixed capital, fluctuations in savings, changes in production structures, etc. However, depending on the direction of causality, many patterns in the structuralist methodology can be interpreted in different ways. In particular, e.g., the accumulation of human capital is, undoubtedly, a most important prerequisite for economic growth due to significant external effects and the dependence on technological development. However, it may also stem from economic growth, as the accumulation of skills is largely the result of work experience and improvements to the education system, contingent upon sustainable growth in output and additional budget spending (Ocampo, 2005).

Another example of subtle causality is related to the post-Keynesian KaldorVerdoorn law, which is based on the assumption that higher labor productivity is often the result, rather than the cause of dynamic economic growth. Similarly, investments, which have traditionally been regarded as a prerequisite for accelerating economic growth, may also be regarded as its result, which is confirmed by econometric analysis. In particular, this means that in an empirically defined investment function for a given country, the capacity utilization factor (defined as lagged output growth) plays a central role as a regressor. At the same time, as follows from an empirical study of economic growth trends during recent decades conducted by some authors, investments do not usually accelerate economic growth by themselves, though they do prevent its deceleration or unexpected crash. ${ }^{5}$

Could exports become a factor in accelerating growth, as described (based on an analysis of a large amount of data on economic growth accelerations) in Jones and Olken (2005)? The issue of export-oriented growth has been examined as a part of structuralist concepts for a long time. According to early structuralists (Prebisch, 2000 [1949]; Hirschman, 1958), export specialization in raw materials, typical of poor economies, may hamper economic development because firstly, primary products generate weak incentives for developing other types of economic activity; and secondly, their relative prices (in comparison to manufactured products) are declining. This is why these authors regarded industrialization as the main driver for accelerating technical progress and improving standards of living.

Later discussions on the importance of an export-oriented strategy suggested that focusing on exports encouraged learning by doing, increased labor productivity and created new comparative advantages (Chenery, 1980), and offset limited domestic demand, which is necessary for increasing the economies of scale inherent (according to many structuralists of that time) in the manufacturing industry. Later papers argued that the advantages of specializing in manufactured products are more closely associated with the complexity of the activity than with the development of manufacturing facilities as such. This is why per capita GDP growth rates are influenced, first of all, by the complexity of the exported goods (Hausmann et al., 2007).

According to the industrialization theorist N. Kaldor (1978 [1966]), foreign demand is necessary to "fuel" manufacturing industry and "disconnect" it from

\footnotetext{
5 "We... find that accelerations and decelerations are asymmetric events. Accelerations are associated with substantial increases in trade, and relatively little change in investment, monetary policy or levels of conflict. Decelerations, on the other hand, show much sharper changes in investment.., increases in monetary instability, and increases in conflict... The roads into and out of rapid growth expansions are both welltrodden. But they are different roads" (Jones and Olken, 2005).
} 
domestic demand. Its development encourages both the structural reallocation of the workforce from relatively low-productive sectors (agriculture in his time) into high-productive sectors, and leveraging the dynamic effects of economies of scale. Later, as globalization processes accelerated, it became evident that imports are also important for sustainable development. Structuralist concepts gave birth to theories that associated economic growth with balance of payments constraints, i.e. with the accumulation of liquidity required to finance imports at the expense of exports and the financial account. This was done as part of the essentially structuralist theories on balance of payments constrained growth (BPCG-models), based on Thirlwall's Law. This approach, used as part of the multisectoral version of Thirlwall's Law (rather than the traditional version), became an option for identifying the sectors that drive economic growth based on a portfolio approach.

\section{Approaches to identifying the sectors that drive economic growth and their significance in developing a structural policy}

The expert community continues to discuss how exactly a structural policy can accelerate growth (except for structural policy measures that encourage labor reallocation from low-productivity to high-productivity industries). In this regard, it remains a relevant problem to identify the sectors that drive economic growth, which can ensure unconditional convergence; see Rodrik, 2013c), which acts as a bonus for advocates of an adequate structural policy. The unconditional convergence of per capita incomes (successful catch-up development) is a result of developing sectors that produce tradable goods, successfully borrowing new technologies, increasing labor productivity and having a beneficial impact on growth rates in adjacent sectors. This convergence is independent of nonstructural factors (geography, policy, institutions, and other country-specific fundamentals), which are important for sustainable growth but cannot substitute for the structural policy that initiates it.

In modern structural analysis, as in structural policy, a number of methods and forms rely on an integrated portfolio approach to find and use the driving sectors that are accelerating economic growth. This means that economic sectors are regarded as a kind of asset portfolio (by analogy, like a financial asset portfolio) where every element (sector, industry) possesses characteristics based on which the portfolio's general parameters can be optimized. Those include growth rate volatility (systemic and non-systemic risk; see Mironov, 2006), and the economic growth rate. These structural policy approaches include, in particular, developed concepts based on New Structural Economics, ${ }^{6}$ on the one hand, and on the "EU smart specialization," on the other. These approaches differ from the sectorneutral horizontal structural policy, which prevailed during the reforms in transitional economies in the 1990s, and rejected any prioritization of sectors or other impact receptors (due to the concern about the lack of information on the correct choice of priorities and the danger of excessive influence by lobbyist groups and corruption). According to the key concept of new structural economics (Growth Identification and Facilitation Framework, GIFF), the sectors offering

${ }^{6}$ On the concepts of new structural economics, see, in particular Lin (2011), Berglof et al. (2015). 
potential or hidden comparative advantages for a developing country should be determined based on those where "goods and services have been produced for roughly 20 years in dynamically developing countries with a similar supply of capital, human, and natural growth factors (factor endowments) and a per capita income that exceeds the actual figure for that country by roughly $100 \%$ " (Lin and Rosenblatt, 2012). According to this approach, the government must develop the infrastructure, invest in human capital, raise direct foreign investments, and pursue a monetary policy (closely coordinating the activities of all regulators) to not only reduce inflation, but also to encourage economic growth and diversify the economy (its sector and asset portfolio), in order to prevent hysteresis and cumulative technological backwardness.

The indications for identifying the sectors - drivers of economic growth can also be obtained using structuralist approaches in their post-Keynesian version, which have been developed, in particular, based on using modern modifications of the so-called Kaldor laws, i.e. the first three and then the fourth, in the form of Thirlwall's Law, including its multisectoral version (Thirlwall, 1979, 2011). The Kaldorian approach, which emphasizes the connection between increasing manufacturing labor productivity (or in other driving sectors) and that of the entire economy, is still an appropriate approach to use for studying economic growth as part of the structuralist paradigm.

Kaldor deduced his growth laws (Kaldor Growth Laws, KGL), namely, on the basis of the correlation between growth in manufacturing, labor productivity across the economy, and GDP growth, emphasizing the significance of economies of scale, technical innovation, and the demand factor (both domestic and foreign). ${ }^{7}$ These laws, formulated as part of post-Keynesian approaches, rely first of all on aggregate demand (Libanio and Moro, 2011, p. 5) and on exports (due to limited domestic demand), and call into question the common nature of constant economies of scale and the homogeneity of the marginal labor product in all economic activities (Freitas, 2003). At the same time, Kaldor did not deny the impacts of technology, individual preferences and the demand factor as a whole; he only stressed that demand was primarily in the economic growth process, in interaction with supply.

The first three Kaldor laws have been the subject of extensive literature, where they have been examined using modern econometric methods and are often confirmed, including cases where additional control variables were added to the model (particularly for the capital factor, ${ }^{8}$ real foreign exchange rate, etc. ${ }^{9}$ ).

\footnotetext{
7 This approach states that expanding the manufacturing sector may stimulate GDP growth via three mechanisms. First: increasing labor productivity in the manufacturing sector spurs increasing labor productivity in other sectors and, eventually, GDP growth. Second: increasing labor productivity in the manufacturing sector is induced by increasing output in the sector, caused by larger economies of scale. Thus, industrialization is an important factor in stimulating overall economic growth. Third: "The faster industry grows, the more labour it will absorb from agriculture and other activities where the marginal product is below the average product (because of diminishing returns), so that as labour transference takes place, labour productivity outside the industrial sector increases and raises the growth of labour productivity in the economy as a whole (and therefore GDP growth)" (Wells and Thirlwall, 2003).

8 The absence of capital as a variable was previously justified by stating its permanence in developed countries during the post-war period (see, e.g., Fingleton and McCombie, 1998, p. 91).

9 See, e.g., Atesoglu (1993), Pons-Novell and Viladecans-Marsal (1999), Felipe et al. (2007), Pieper (2003), Di Meglio et al. (2015).
} 
At the same time, the leading role of the manufacturing sector has been brought into question lately, based on new data regarding the improving tradability of the services sector and the expansion of its role in global value (Matsuyama, 2009), as well as growth in its innovation and productivity (Timmer and de Vries, 2009; Maroto-Sánchez and Cuadrado-Roura, 2009; Park and Shin, 2012).

Nevertheless, it remains unclear whether we can fully abstract from the arguments stating that the growth of labor productivity in the services sector can be relatively low in the long run. ${ }^{10} \mathrm{~A}$ need arises to verify the relevance of the first three of Kaldor's Growth Laws to the modern economy, using a single methodology to test for growth drivers not only in manufacturing, but in other sectors as well (as has been done in a number of papers). As for Kaldor's fourth law, it was later transformed into the so-called Thirlwall Law using traditional Keynesian approaches. Kaldor's concept ignored the fact that the income elasticity of demand for imported goods may be such that quick output growth may lead to imbalanced growth in imports relative to exports, which would trigger a crisis in the balance of payments. This controversy was resolved in the law described in Thirlwall (1979), which is sometimes called the Kaldor-Thirlwall Law, and states that "the equilibrium growth rate in any one region is a product of the world income growth rate and the ratio of the income elasticities of demand for exports and imports" (Setterfield, 2011), i.e. economic growth is limited by the balance of payments (balance-of-payments-constrained growth-BoPC).

According to Thirlwall's Law:

$$
g_{B}=\frac{e z}{\pi}=\frac{x}{\pi}
$$

where: $g_{B}$ is a country's GDP growth rate, consistent with the long-term equilibrium of the balance of payments; $e$ is the income elasticity of the demand for exports; $z$ is the income growth rate in foreign countries; $x$ is the growth rate of exports; $\pi$ is the domestic income elasticity of demand for imports. A detailed theoretical and formal justification of Thirlwall's Law in its canonic form (without isolating the sectoral aspect) is given in Thirlwall $(1979,2011)$ and in Gurvich and Prilepskiy (2013).

Soukiazis and Cerqueira (2012) aggregate the research conducted based on Thirlwall's Law, as well as numerous expansions of the basic model by including capital flows, interest payments on debt, and trends in trade terms and trade partners. In Gurvich and Prilepskiy (2013), Thirlwall's Law in its traditional form (aggregated, without any breakdown by sector) is used to analyze and forecast the Russian economy.

According to Thirlwall's Law, the indicators of income elasticity for exports and imports, which essentially represent the two sides of a country's non-price competitiveness, are comparable to a certain extent to the "Solow residual," as they play a central role in explaining growth (Dávila-Fernández et al., 2018).

\footnotetext{
${ }^{10}$ These arguments usually include the following: "(1) Services are intensive in labor rather than capital, making it difficult to achieve innovation, which is embodied in capital; (2) services sector firms are too small to devote adequate resources to research and development or to risk new production techniques; (3) international competition is weak because most services are nontradable; and (4) a lot of employment in services reflects underemployment of individuals who cannot find jobs in other places" (Park and Shin, 2012).
} 
Therefore, given the generally successful empirical verification of Thirlwall's Law in its traditional form (aggregated, without a breakdown by sector), ${ }^{11}$ an idea appeared to endogenize the income elasticity of foreign trade. This endogenization followed various trajectories: based on the technical competitiveness concept (Meliciani, 2002; Cimoli and Porcile, 2014), integrating the reverse impact of growth on non-price competitiveness into the model (Fiorillo, 2001; Setterfield, 2011), integrating capital accumulation factors into the import function (Palley, 2003), and the real foreign exchange rate (Oreiro, 2016). P. Krugman (1989) developed a model that he called the "45 Degree Rule" which was similar to Thirlwall's Law, assuming that the elasticity of foreign trade activity is endogenous to productivity.

Another path for endogenizing the indicators of country's foreign trade competitiveness is to transform an aggregated model into a disaggregated model based on the integration of the tradable sectors portfolio (Fiorillo, 2001; Araújo and Lima, 2007; Nishi, 2016). In this case, non-price competitiveness is endogenized by changes in the economic structure with respect to its tradable sectors. Pasinetti (1981, 1993; see Araujo and Lima, 2007, p. 756) proposed a model for structural economic dynamics (SED), according to which growth is affected by specific leading sectors. In Araujo and Lima (2007), the balance of payments equilibrium was added to Pasinetti's model, as required by Thirlwall's Law in its basic (not multisectoral) version. If an economy has $n$ sectors, the equation can be rewritten using the share of each sector in total imports and exports:

$$
g_{B}=\frac{\sum_{j=1}^{n} a_{j} e_{j} z}{\sum_{j=1}^{n} b_{j} \pi_{j}}
$$

where: $a_{j}$ is the share of exports for sector $j$ out of total exports; $b_{j}$ is the share of imports for sector $j$ out of total imports; $e_{j}$ is the external income elasticity of demand for the sector's exports; $z$ is the income growth rate in foreign countries; $\pi_{j}$ is the domestic income elasticity of demand for imports into the sectoral market.

According to equation (2), the economy will grow faster if foreign demand accelerates, the sectoral income elasticity of imports $\pi$ is lower, and sectoral income elasticity for exports $e$ is higher. The conclusions for an optimal policy, according to the equilibrium trade balance approach, suggest optimizing the combination of export promotion and import substitution with domestic production (import substitution) taking the economic structure into account. Since the GDP growth rate in this model depends not only on the sectoral elasticity of imports and exports, but also on each sector's share of the country's total exports and imports, an optimal policy (maximizing GDP growth) should take both factors into account (i.e. be developed subject to the two-dimensional constraint). The main conclusion from this sectoral model is that even if the income (foreign and domestic demand) elasticity of exports and imports is constant, and there is no general economic growth in the world, a country can increase its growth rates by changing its industry ratios. This kind of "autonomous acceleration" is also possible in

\footnotetext{
${ }^{11}$ Read about the testing of the law in, e.g., Bagnai (2010), Lanzafame (2014), Bagnai et al. (2016).
} 
the case of a constant sectoral share of exports and imports, and in the case where sectors have increasing domestic and foreign competitiveness, as measured by the foreign and domestic demand elasticity for their exports and imports (taking the price factor into account).

The multisectoral version of Thirlwall's Law underwent successful empirical testing in a number of papers, in particular, Gouvea and Lima $(2010,2013)$, for developing economies, and Romero and McCombie (2016), for 14 developed countries. As shown in the latter study, according to the results obtained for a sample of developed European countries based on modern methodologies (including panel regressions), both the standard and multisectoral versions of Thirlwall's Law act as acceptable predictors of growth rates.

\section{Tentative model version for the Russian economy model based on the multisectoral version of Thirlwall's Law}

It is generally recognized that the Russian economy is characterized by its dependence on resources and is possibly affected by the "resource curse". Out of the six specific factors identified in the literature, given that the availability of abundant natural resources may lead to poor economic performance, ${ }^{12}$ we believe two factors to be most relevant for Russia's economy. The first factor is the higher volatility of export revenues than in non-commodity economies (resulting in an unstable balance of payments, rouble rate, and budget processes); second, is exposure to "Dutch Disease" which results in a simplified economic structure. The payment balance factor is, in our opinion, especially relevant for non-diversified commodity-based economies, where exports and imports act as a function of external commodity prices (primarily oil and gas in Russia) mediated by the foreign exchange market. At the same time, import and export trends and their income elasticity are vital characteristics of a country's longterm competitive performance in the domestic and foreign markets. Therefore, when analyzing the Russian economy, it may be advisable (in addition to other approaches) to use economic growth rate estimates and forecasts derived from the dynamic foreign trade multiplier model (Harrod, 1939) which, as structuralist concepts evolved, was developed by Thirlwall into an empirically verified hypothesis arguing that, subject to constant terms of trade, "the rate of growth... of any country in the long run is equal to the growth rate of the volume of exports... divided by the income elasticity of demand for imports..." (Thirlwall, 2011, p. 309), i.e. into the so-called Thirlwall Law.

In this regard, to identify sectors within the Russian economy that would boost long-term GDP growth rates if their share was increased, the aforementioned approach can be pursued within the framework of the multisectoral version of Thirlwall's Law. The macro model built based on this approach assumes that a country's long-term GDP growth rates are contingent upon its nominal exports

\footnotetext{
12 In particular, Frankel (2012) analyzes the literature to identify the following six hypotheses regarding factors which adversely affect long-term growth rates in resource-based economies: (1) long-term global commodity pricing trends; (2) commodity price volatility; (3) the constant squeezing out of manufacturing facilities having a positive impact on long-term economic growth rates; (4) autocratic or oligarchic institutions; (5) anarchic institutions: weak ownership, rapid depletion of natural resources, civil war; (6) cyclical expansion of the non-tradable sector due to "Dutch Disease."
} 
by sectors (their weighted shares out of total exports) ${ }^{13}$ divided by the domestic demand growth elasticity of each sector's imports (elasticity is also weighted based on the share of sectors out of total imports). The cited calculations to build a tentative multisectoral Thirlwall model for the Russian economy (Table 2) signify that, given the ratios of industrial sector growth rates and changes in foreign and domestic demand (as characterized by each sector's competitiveness indicators) in recent years, and exogenously introduced annual average growth rates for the global economy and exports $(3.5 \%)$, the overall growth rates for the Russian economy stand as low as $1.8 \%$. The underlying reason is that each sector's competitiveness is generally low: the average weighted foreign demand elasticity for

Table 2

Characteristics of Russian industrial sectors and their competitiveness indicators.

\begin{tabular}{|c|c|c|c|c|c|c|}
\hline \multirow[t]{3}{*}{ Sector } & \multicolumn{4}{|c|}{2017 Indicator } & \multicolumn{2}{|c|}{$\begin{array}{l}\text { Annual average } \\
\text { elasticity in sector }^{\text {a) }} \text {, } \\
2002-2016\end{array}$} \\
\hline & \multicolumn{2}{|l|}{ Exports } & \multicolumn{2}{|l|}{ Imports } & \multirow{2}{*}{$\begin{array}{l}\text { Exports } \\
\text { Foreign } \\
\text { demand } \\
\text { increase }\end{array}$} & \multirow{2}{*}{$\begin{array}{l}\text { Imports } \\
\text { Domestic } \\
\text { demand } \\
\text { increase }\end{array}$} \\
\hline & $\begin{array}{l}\text { Growth in } \\
\text { comparable } \\
\text { prices, } \\
\text { y-o-y, } \% \text { b) }\end{array}$ & Share, $\%$ & $\begin{array}{l}\text { Growth in } \\
\text { comparable } \\
\text { prices, } \\
\text { y-o-y, } \% \text { b) }\end{array}$ & Share, $\%$ & & \\
\hline Overall economy & 103.2 & 0.0 & 117.9 & 0.0 & $0.6(0.8)^{\mathrm{c})}$ & $2.3(1.5)^{\mathrm{c})}$ \\
\hline $\begin{array}{l}\text { Food products and } \\
\text { agricultural raw materials } \\
\text { (except textiles) }\end{array}$ & 116.4 & 5.8 & 110.3 & 12.7 & 1.8 & 0.4 \\
\hline $\begin{array}{l}\text { Mineral products (including } \\
\text { fuel and energy) }\end{array}$ & 100.9 & 60.0 & 113.4 & 2.0 & 0.7 & 1.4 \\
\hline Chemical products, rubber & 103.4 & 6.7 & 108.4 & 17.8 & 0.8 & 1.4 \\
\hline $\begin{array}{l}\text { Raw hides, furs, } \\
\text { and derivative products }\end{array}$ & 104.4 & 0.1 & 134.5 & 0.5 & 0.8 & 1.5 \\
\hline Wood and paper products & 109.1 & 3.3 & 108.2 & 1.6 & 0.8 & 1.2 \\
\hline $\begin{array}{l}\text { Textiles, textile products } \\
\text { and footwear }\end{array}$ & 116.0 & 0.3 & 133.5 & 6.0 & -0.7 & 0.4 \\
\hline $\begin{array}{l}\text { Precious stones, metals, } \\
\text { and derivative products }\end{array}$ & $\mathrm{n} / \mathrm{a}$ & 3.1 & $\mathrm{n} / \mathrm{a}$ & 0.2 & 0.4 & 3.5 \\
\hline $\begin{array}{l}\text { Metals and derivative } \\
\text { products }\end{array}$ & 105.1 & 10.8 & 132.3 & 6.9 & 0.3 & 2.9 \\
\hline $\begin{array}{l}\text { Machinery, equipment, } \\
\text { and vehicles }\end{array}$ & 102.6 & 7.8 & 121.2 & 48.6 & 0.7 & 1.7 \\
\hline Other & 85.7 & 2.0 & 119.2 & 3.8 & 3.0 & 2.4 \\
\hline
\end{tabular}

a) The demand elasticity of exports (imports) is estimated econometrically using annual data, incorporating the effect of foreign and domestic demand (and real foreign exchange rates) trends on physical exports (imports) within an industry. Foreign demand is estimated as the growth of exports in respective industries in the global economy (according to the WTO), domestic demand is estimated as the growth of domestic output in sectors, and the real effective rouble exchange rate trend as one of the regressors is estimated based on BIS data. Physical exports and imports are estimated based on FCS data.

b) Estimate for three quarters of 2017.

c) The first digit refers to estimates based on data for the overall economy (not weighted based on the share of sectors out of total exports and imports); the second digit (in parenthesis) refers to the sector-weighted average export and import elasticity.

Source: Authors' calculations.

\footnotetext{
${ }^{13}$ At the same time, export volume in nominal terms is predicted based on, first, the estimated foreign demand elasticity of exports by sector, second, the exogenously introduced foreign demand trends, and third, the share of sectors in the country's total exports.
} 
each sector's exports is, retrospectively, only 0.8 , whereas the domestic demand elasticity for imports in each sector is appreciably higher than 1 (1.5; see Table 2).

Preliminary calculations based on the constructed model (which may be adjusted later as quarterly data calculations follow the annual data, and during the model modification) demonstrate that if we assume that the export competitiveness of Russian economic sectors could increase in a way that the elasticity of exports in backward sectors grew to 1 (at the same high level of elasticity of imports [ $>1]$ in all sectors and the export competitiveness of producers of food and other goods; see Table 2), then, hypothetically, GDP growth rates in the Russian economy could increase to $2.6 \%$. If a similar hypothesis is adopted with respect to domestic competitiveness, as measured by the sectoral elasticity of imports, i.e. in the case whereby we assume a decline in the domestic demand elasticity of imports in the least competitive sectors down to at least 1 (given that the competitiveness of food and textile producers remains below 1; see Table 2), then the growth rates of the Russian GDP would rise to $3.6 \%$. If both prerequisites were met, GDP growth rates in Russia would rise to $4 \%$, exceeding the exogenously introduced global average of $3.5 \%$.

Economic growth can also be accelerated by a relative increase in the share of advanced sectors where the elasticity of exports is high (e.g., in the Russian food sector) while that of imports is low (in mechanical engineering). Thus, from a theoretical point of view, GDP growth rates in Russia could be increased even with the global economy's previous growth rates, provided that a reasonable structural policy is pursued, which focuses on the optimal combination of improving sector competitiveness and changing the proportion of the country's total exports and imports that specific sectors provide. At the same time, from the standpoint of theory and calculations, we need to solve the two-dimensional optimization challenge and determine the amount of investment and the scale of other general economic and structural policy measures that affect sector competitiveness and/or the variance of their shares in the country's foreign trade flows. An examination of these matters (including a study and econometric analysis of the development of sectors and the economic policies implemented in other countries), as well as the modernization of the multisectoral economic growth model used in this paper, will be the subject of our future research.

\section{Structural constraints on Russia's economic growth and structural policy}

The reference points for an economic policy focused on changing the competitiveness of Russian economic sectors and their share of foreign trade flows, and produced by structuralist model constructions based on Thirlwall's Law, described in the previous section, need to be complemented by other policy measures aligned with both the structural features of the Russian economy and the current phase of the economic cycle.

Following the Russian economy's strong recovery between mid-2016 and mid-2018 after a recession caused by the sharp decline in oil prices in 2014, economic growth slowed down during Q3 2018. And although 2018 GDP exceeded the 2014 pre-crisis level by around $0.6 \%$ in real terms, the prospects for maintaining growth, let alone accelerating it, are rather vague, as the growth in exports, 
wages, and business profits observed in 2018 resulted largely from situational factors. In conjunction with volatile oil prices, household and corporate income, affected by the sharp spike in economic uncertainty in 2014, are not readily translating into rising domestic demand, whereas monetary and fiscal policies are forcibly conservative, which is reflected in the rising budget surplus (despite the low rates of economic growth), and in the fact that the Bank of Russia's key rate has been positive for a long time. Meanwhile, the positive contribution made by changes in reserves, which also encouraged an economic recovery due to optimism around a new U. S. administration coming to power in 2017, has also been exhausted.

The structural heterogeneity of the Russian economy, reflected in the weak state of the modern high-tech sectors, is seriously affecting its future development prospects. The future growth rates of Russia's GDP can be estimated based on the pre- and post-crisis trends for tradable (mostly industry and agriculture) and non-tradable sectors. The inertial (trend-caused) dynamics of industry is around $1.8 \%-2.0 \%$ per annum, judging by Rosstat and HSE data for the period starting from the beginning of $2016 .{ }^{14}$

At the same time, trends in the non-tradable sectors, which made a decisive contribution to Russia's GDP growth due to rapidly growing trade, construction, and real estate transactions, will be limited. This is because the sharp rise in commodity prices (primarily oil) used to serve as the principal factor in the growth of demand for the services of the non-tradable sectors (including budget-funded). However, they dropped considerably at the end of 2018. In this connection, trends in the non-tradable sectors, accounting for at least $2 / 3$ of the GDP, will hardly be able to exceed growth rates in the tradable sectors (primarily manufacturing). Consequently, growth rates for the economy as a whole will most likely fluctuate between $1.5 \%$ and $2.0 \%$, at least during the next year or two. Moreover, it should be taken into account that the share of agriculture, which has increased output at a rapid rate in recent years, is not large (around 4\% of GDP in 2017), while its trend, affected by the Russian climate and underdeveloped technology, is still unstable (in 2018, agricultural output decreased by roughly $1 \%$ ).

Talking about acceleration of economic growth, one should keep in mind the necessity, described in the literature, to distinguish between economic policy factors initiating (or "igniting") economic growth, on the one hand, and those maintaining it, on the other hand (the so-called factors of proximate and ultimate causality; Maddison, 1991; Rodrik, 2003). In this regard, along with discussing the fundamental steps to support economic growth, it is always important to find ways - specific to a given country - to impart the initial momentum to revive it at a certain point in time (e.g., when the economy ceases to stagnate).

As shown in the literature, there is a set of standard steps for accelerating economic growth in the short run. These steps are associated, first of all, with affecting the mindsets and expectations of economic agents and removing "government failures" in economic regulation, with "debureaucratization" and increasing the elasticity of supply for production factors over their demand (Rodrik, 2003;

\footnotetext{
${ }^{14}$ Industrial growth accelerated to $2.9 \%$ in 2018 , from $2.1 \%$ in 2017 , although this was mainly driven by extracting segments and temporary factors. In 2017, as part of a treaty with OPEC+, Russia was forced to adjust oil production volumes $(-0.3 \%$ compared with 2016$)$, whereas in July 2018 , the terms of the treaty were made more favorable for Russia: oil production increased by $1.7 \%$ in 2018 .
} 
Golodnikova et al., 2018; Ocampo, 2005). However, these steps, not unlike more fundamental steps, may result in redistributing the spheres of influence of the elites and, therefore, be quite painful from a political and economic point of view.

Based on global experience, and subject to the studies carried out within the modern structuralist paradigm, economic policy measures initiating growth are usually associated with quick structural changes in the economy. As shown in Ocampo (2005) (with reference to Aghion and Howitt, 1992, 1998; Schumpeter, 1962 , ch. VIII), the concept of a growing economy as an "inflating balloon," according to which additional production factors and sustainable technological changes gradually increase the total GDP, may serve as a useful metaphor for certain purposes. But, eventually it fails to take into account some of the most significant components of economic development (and technological changes). An alternative prospect, based on structural economic thought (in a broad sense), regards growth as a dynamic process where some sectors and firms outperform others as part of the constant transformation of production structures. This process includes the repeated phenomenon of "creative destruction" (Ocampo, 2005). The ability to constantly generate new dynamic activities - in fact, innovations in a broad sense - is a vital factor in driving fast-paced economic growth.

Considering imparting initial momentum to economic growth, it is important that, based on the global experience, it represents a leap rather than a stable transition between stages; it is accompanied by the disappearance of some sectors and economic activities, and the appearance of others. Using a metaphoric expression by a renowned economist, this kind of growth is not a gradual, "yeast-like" process (or the expansion of a gradually inflated balloon) but, rather, the growth of mushrooms after rainfall (Harberger, 1998).

As shown above and in De Vries et al. (2012), McMillan and Rodrik (2011), for many countries, one of the most significant factors driving labor productivity growth at the macro level and the emergence of new sectors is now the alteration of the employment structure caused by reallocating labor from low-productivity to high-productivity industries. This process has occurred in many developed countries (notably, the intensity of structural changes is considered one of the factors behind their differing growth rates; see Maddison, 1987; Dietrich, 2012) and is more intrinsic to developing countries.

For example, in China (as in the USSR in the 1930s, and in many developing countries), this labor reallocation from agriculture to manufacturing during certain periods was at least equally important for accelerating GDP growth as the inflow and generation of new technology and modernizing economic regulatory systems (Fan et al., 2003).

However, in the Russian economy the manufacturing industry (with some exceptions) is underdeveloped both in terms of technology and administration. In the 2000s, labor productivity growth rates in this sector were not far ahead of the national average rates, let alone the extraction sector (Fig. 2 and Table 3).

We can clearly observe the superiority of the extracting industry over all other economic activities in terms of labor productivity in absolute terms (see Fig. 2 and Table 3). Between 2002 and 2016, it exceeded the national average by 4.4-4.6 times (this is attributable, to a large extent, to the price rent accumulated by the industry during the period of high oil prices) and was more preferable than other sectors in terms of financial conditions for industrial modernization. Meanwhile, the opportu- 


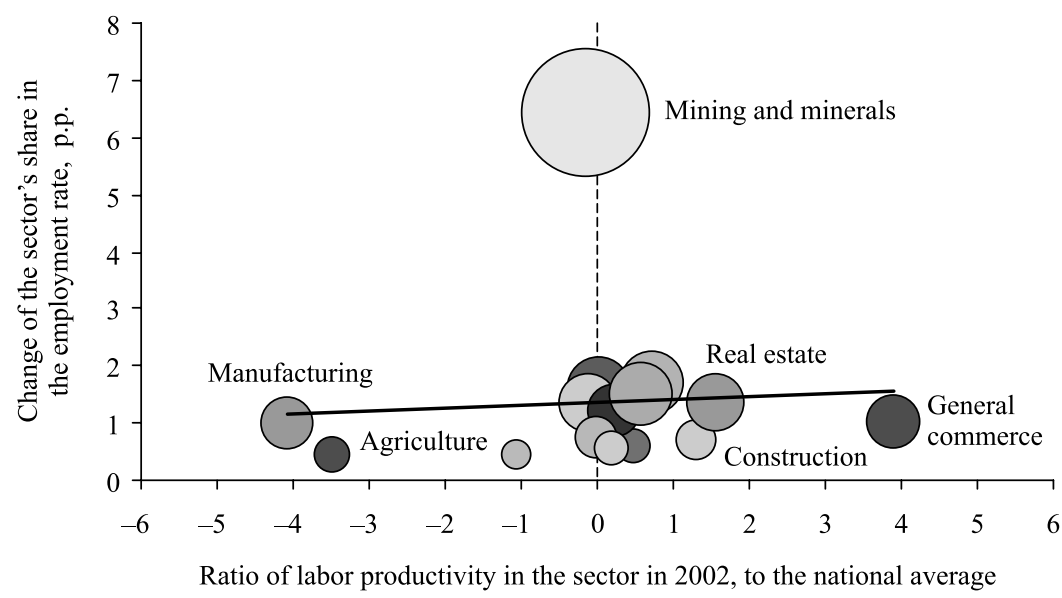

Fig. 2. Structural shifts in the labor market in the Russian economy from 2002 to 2016.

Note: The size of the circle is the absolute labor productivity level in 2002.

Source: Authors' calculations based on Rosstat data.

nities for the oil and gas sector to attract new employees are not very abundant due to the limited foreign demand for commodities. In 2002, there were 1.16 million employees in the sector ( $1.8 \%$ of all employed persons in the economy), whereas by 2016 , this figure had actually decreased by 78,000 , while overall employment in the economy had increased by around 1.5 million (see Table 3 ).

Thus, neither the extraction, nor the manufacturing sector ensures a reallocation of labor, which facilitates relatively easy productivity growth across the economy. The Russian extracting industry demonstrated its lowest outflow, whereas the outflow from the manufacturing industry (as with agriculture) is quite considerable. For example, the outflow of employees from this sector was around 2.4 million during the period under review, while its share of total employment dropped by 4 p.p., to slightly above $14 \%$ in 2016 . There was an inflow in commerce and commercial services, i.e. in the sectors creating low value added per employee, which is typical for a country affected by "Dutch Disease" and premature deindustrialization.

Against the persistent relative share of manufacturing in the global economy (taking into account the increase in China's specific weight), the growing unit labor costs in Asia, and the sophistication and "customization" of production caused by technical progress, reindustrialization (particularly in the form of reshoring) is taking place in developed countries and in competitive developing economies. These processes are observed first of all in sectors where technical progress is leading to cheaper and more advanced robots, lowering the need for cheap human labor.

It is vital to consider reindustrialization and reshoring processes in terms of competition for the migrating manufacturing sector, and in terms of the emergence of opportunities for moving part of the "world factory" workshops from China to other countries (including Russia, where ruble devaluation has reduced specific costs, while the "transportation leg" to European and other markets is shorter). It should be noted that the scale of the expansion in goods produced by the country depends not only on the specific costs of resources, but also "on the accumulated baggage of production experience in particular industries, 
Table 3

Characteristics of the labor market and trends in labor productivity (LP) in the Russian economy, 2002-2016.

\begin{tabular}{|c|c|c|c|c|c|c|}
\hline \multirow[t]{3}{*}{ Industry } & \multicolumn{3}{|c|}{$\begin{array}{l}\text { Employment rates in sectors of } \\
\text { the Russian economy in } 2016 \text { (estimate) }^{\text {a) }}\end{array}$} & \multirow{2}{*}{\multicolumn{2}{|c|}{$\begin{array}{l}\text { Ratio of } \\
\text { absolute LP } \\
\text { levels to } \\
\text { the national } \\
\text { average, times } \\
\end{array}$}} & \multirow{3}{*}{$\begin{array}{l}\text { Annual } \\
\text { average LP, } \\
\% \text { (Rosstat } \\
\text { data) } \\
2003-2015\end{array}$} \\
\hline & \multirow[t]{2}{*}{$\begin{array}{l}\text { thousands } \\
\text { of people }\end{array}$} & \multirow[t]{2}{*}{$\begin{array}{l}\% \text { of } \\
\text { total }\end{array}$} & \multirow{2}{*}{$\begin{array}{l}\text { growth } \\
\text { in } 2016 \\
\text { compared to } \\
2002, \%\end{array}$} & & & \\
\hline & & & & 2002 & 2016 & \\
\hline $\begin{array}{l}\text { Total, } \\
\text { including: }\end{array}$ & 67138.7 & 100.0 & 102.4 & & & 3.4 \\
\hline $\begin{array}{l}\text { Agriculture, hunting, } \\
\text { forestry }\end{array}$ & 6045.8 & 9.4 & 73.5 & 0.33 & 0.35 & 3.1 \\
\hline Fishery, fish farming & 141.7 & 0.2 & 118.1 & 1.16 & 0.72 & 0.2 \\
\hline Mining and minerals & 1084.9 & 1.6 & 93.3 & 4.64 & 4.43 & 3.3 \\
\hline Manufacturing & 9622.9 & 14.8 & 79.6 & 0.74 & 0.73 & 4.9 \\
\hline $\begin{array}{l}\text { Electric power, } \\
\text { gas, and water } \\
\text { production and } \\
\text { distribution }\end{array}$ & 1856.2 & 2.9 & 98.2 & 0.98 & 0.90 & 0.9 \\
\hline Construction & 5407.0 & 8.4 & 121.3 & 0.52 & 0.65 & 3.6 \\
\hline $\begin{array}{l}\text { Wholesale and } \\
\text { retail trade, } \\
\text { repair services }\end{array}$ & 12737.5 & 18.3 & 128.7 & 0.76 & 0.64 & 3.3 \\
\hline Hotels and restaurants & 1409.6 & 1.9 & 131.0 & 0.42 & 0.32 & 1.7 \\
\hline $\begin{array}{l}\text { Transportation and } \\
\text { telecommunications }\end{array}$ & 5389.3 & 8.0 & 105.4 & 0.88 & 0.77 & 3.9 \\
\hline Financial operations & 1208.3 & 1.9 & 169.0 & 1.23 & 2.11 & 3.6 \\
\hline $\begin{array}{l}\text { Real estate } \\
\text { transactions, } \\
\text { leasing, and services }\end{array}$ & 6071.3 & 8.6 & 123.6 & 0.99 & 1.49 & 3.1 \\
\hline $\begin{array}{l}\text { State administration } \\
\text { and military } \\
\text { security; } \\
\text { social security }\end{array}$ & 3613.2 & 5.5 & 115.1 & $\mathrm{n} / \mathrm{a}$ & $\mathrm{n} / \mathrm{a}$ & $\mathrm{n} / \mathrm{a}$ \\
\hline Education & 5457.7 & 8.2 & 90.4 & $\mathrm{n} / \mathrm{a}$ & $\mathrm{n} / \mathrm{a}$ & $\mathrm{n} / \mathrm{a}$ \\
\hline $\begin{array}{l}\text { Healthcare and social } \\
\text { services }\end{array}$ & 4484.8 & 6.7 & 102.0 & $\mathrm{n} / \mathrm{a}$ & $\mathrm{n} / \mathrm{a}$ & $\mathrm{n} / \mathrm{a}$ \\
\hline $\begin{array}{l}\text { Other utility, social, } \\
\text { and personal } \\
\text { services }\end{array}$ & 2512.4 & 3.7 & 107.7 & $\mathrm{n} / \mathrm{a}$ & $\mathrm{n} / \mathrm{a}$ & $\mathrm{n} / \mathrm{a}$ \\
\hline
\end{tabular}

a) The authors' estimate based on Rosstat data on the employment rate in the economy from 2002 to 2015, and regular monthly statistics on the number of vacancies filled in 2016.

Source: Authors' calculations based on Rosstat data.

on the ability to create new competitive facilities and to fight the dependence on the previously chosen path and institutional inertia" (Romano and Trau, 2017).

On the whole, the dependence of the labor reallocation on the factor of higher labor productivity in Russia is still low (see Fig. 2). The transformation of such a reallocation into a significant economic growth factor requires new seeds of growth and high productivity at the sectoral level.

As shown in $\mathrm{Vu}$ (2017), based on econometric calculations for 19 Asian countries between 1970 and 2012, structural changes have a quick positive effect on the growth of labor productivity, wages, and GDP in general, but lead to higher unemployment in the short-run. In this regard, the author stresses the importance of preventive measures for retraining dismissed employees and assisting them in finding new jobs. In order to ensure structural shifts at all production levels, we 
need to improve the business environment and the legal framework, i.e. to stimulate competition, facilitate mergers and acquisitions, and normalize bankruptcy procedures. To launch economic growth, we also need structural policy measures, particularly to protect entrepreneurs pioneering innovations (including simulations) from being quickly copied (Hausmann and Rodrik, 2003).

In order to launch "creative destruction" processes, we need to relax labor market rigidity, improve workforce mobility, and lift the most stringent restrictions on employee dismissals (provided that the state undertakes to retrain and relocate employees and their families to new production sites). Notably, according to ratings by the World Economic Forum on labor market adaptivity (flexibility), Russia lags behind its neighbors that are equally dependent on commodity exports, i.e. Kazakhstan and Azerbaijan.

In any case, to encourage growth, it is hardly advisable to focus on undertaking all currently possible reforms incorporating existing data and opportunities for economic agencies, or for calculating the macroeconomic effects of certain projects generated by the stronger players or business groups, which may obtain government aid for their implementation. All this describes an approach that we could call "bottom-up". But, after reviewing the global experience, it seems that in diagnosing growth and elaborating measures to maintain it in structurally heterogeneous economies like Russia (dominated by export and commodity companies), it is more advisable to take a "top-down" approach. That is, we should begin by using a special methodology to identify the most significant real constraints on economic growth, which may "bottleneck" it, relying, e.g., on the famous methodology of interactive growth diagnostics at the country level (Hausmann et al., 2008; Rodrik, 2010), modified to suit the structural heterogeneity of the Russian economy, or on the technology of interactive diagnostics of export competitiveness (e.g., based on World Bank methodologies modified using AI technology, which may be advisable in view of the great mass of continually updated information broken down by exported goods and national markets).

\section{Conclusion}

An acceleration of the growth rates in the Russian economy, which have not exceeded an average of $1 \%$ during the past decade, should consider its structural heterogeneity and the results of studies completed within the structuralist scientific paradigm. In this connection, the strategic objective of diversifying the Russian economy is becoming ever more relevant, which (unlike tactical objectives to maintain the country's current solvency) was not achieved by previous approaches to building economic policy that were focused on structurally homogeneous economies. To maintain the growth and diversification of a transition commodity-based economy (like Russia), the state must be active in providing information about new industries, coordinate related investments, compensate for information externalities for firms entering new markets, and help emerging industries through incubation processes and attracting foreign investment (Lin, 2011; Lin and Chang, 2009; Lin and Monga, 2011). The state also must effectively perform its leadership functions to improve infrastructure, thereby reducing the transaction costs for individual firms and removing barriers along the path to reconfigure the economy and increase its adaptation potential. 
As follows from the analysis of the literature on the genesis of "economic miracles," i.e. unexpected and enduring growth accelerations, the measures which led to success cannot be directly borrowed. There are many case studies describing unconventional transitions to a market economy, taking into account both the current reality and the past legacy. It is not impossible that the trajectory of accelerating economic growth in Russia is contingent upon higher ingenuity in searching for effective forms to implement the standard vectors of economic policy.

After initiating growth through structural policy measures, it is important to make it sustainable. This requires long-term fundamental reforms, including improvements to the judicial system, developing fair competition, and other steps to improve institutions. These reforms must make social institutions inclusive, aimed at fighting corruption, and ensure open and fair access for all population groups to production factors and the results of economic development.

It should also be taken into consideration that market-managed diversification of the industry portfolio can be regarded as the first stage of transition to diversified development, including not only improved diversity in the industry portfolio, but also diversification in the portfolio of national assets (both tangible and intangible). The latter, in particular, requires intensified investment in infrastructure, the preservation of natural resources, and developing institutions and human capital. This objective, seen as a transition to a diversified economy through diversified development (and not only stimulation of the industry portfolio diversification), is strategically relevant for all commodity-based economies exposed to the "resource curse" (see more in Gill et al., 2014). Resource dependence means not only the presence of structural distortions and "Dutch Disease," but the imperfection of institutions, the weakness of labor and investment incentives (including human capital), the volatility of proceeds from commodity exports against the trend towards their rapid decline relative to the GDP.

\section{Acknowledgements}

The study was conducted as part of applied scientific research by HSE in 2017 and 2018, entitled "Structural changes in the Russian economy and structural policy," and in the framework of the 2019 HSE fundamental research program. The authors express their gratitude to Alexey Kuznetsov and Natalia Samsonova for their contributions to preparing the literature survey and their help in several calculation tasks.

\section{References}

Acemoglu, D. (2009). Introduction to modern economic growth. Princeton University Press.

Aghion, P., \& Howitt, P. (1992). A model of growth through creative destruction. Econometrica, 60 (2), 323-351.

Aghion, P., \& Howitt, P. (1998). Endogenous growth theory. Cambridge, MA: MIT Press.

Aghion, P., Jones, B. F., \& Jones, C. I. (2017). Artificial intelligence and economic growth. NBER Working Paper, No. 23928.

Araujo, R. A., \& Lima, G. T. (2007). A structural economic dynamics approach to balance-ofpayments-constrained growth. Cambridge Journal of Economics, 31 (5), 755-774. 
Atesoglu, H. S. (1993). Manufacturing and economic growth in the United States. Applied Economics, $25(1), 67-69$.

Bagnai, A. (2010). Structural changes, cointegration and the empirics of Thirlwall's law. Applied Economics, 42 (10), 1315-1329.

Bagnai, A., Rieber, A., \& Tran, T. (2016). Sub-Saharan Africa's growth, South-South trade and the generalised balance-of-payments constraint. Cambridge Journal of Economics, 40, 797-820.

Baranzini, M., \& Scazzieri, R. (eds.) (1990). The economic theory of structure and change. CUP Archive.

Baumol, W. J. (1967). Macroeconomics of unbalanced growth: The anatomy of urban crisis. American Economic Review, 57 (3), 415-426.

Berglof, E., Foray, D., Landesmann, M., Lin, J. Y., Campos, M. N., Sanfey, P., Radosevic, S., \& Volchkova N. (2015). Transition economics meets new structural economics. Journal of Economic Policy Reform, 18 (3), 191-220. https://doi.org/10.1080/17487870.2015.1018691

Blankenburg, S., Palma, J. G., \& Tregenna, F. (2008). Structuralism. In S. N. Durlauf, \& L. E. Blume (Eds.), The New Palgrave dictionary of economics (vol. 8, pp. 69-74). Basingstoke: Palgrave Macmillan.

Cimoli, M., \& Porcile, G., (2014). Technology, structural change and BOP-constrained growth: A structuralist toolbox. Cambridge Journal of Economics, 38 (1), 215-237.

Chenery, H. B. (1980). Interactions between industrialization and exports. American Economic Review, 70 (2), 281-287.

Clark, C. (1957). The conditions of economic progress. London: Macmillan \& Co.

Dávila-Fernández, M. J., Oreiro, J. L., \& Dávila, M. W. (2018). Endogenizing non-price competitiveness in a BoPC growth model with capital accumulation. Structural Change and Economic Dynamics, 44, 77-87.

De Vries, G. J., Erumban, A. A., Timmer, M. P., Voskoboynikov, I., \& Wu, H. X. (2012). Deconstructing the BRICs: Structural transformation and aggregate productivity growth. Journal of Comparative Economics, 40 (2), 211-227.

De Vries, G., Timmer, M., \& de Vries, K. (2015). Structural transformation in Africa: Static gains, dynamic losses. The Journal of Development Studies, 51 (6), 674-688.

Dietrich, A. (2012). Does growth cause structural change, or is it the other way around? A dynamic panel data analysis for seven OECD countries. Empirical Economics, 43 (3), 915-944.

Di Meglio, G., Gallego, J., Maroto, A., \& Savona, M. (2015). Services in developing economies: A new chance for catching-up? SPRU Working Paper Series, No. 2015-32.

Fagerberg, J. (2000). Technological progress, structural change and productivity growth: A comparative study. Structural Change and Economic Dynamics, 11 (4), 393-411.

Fan, S., Zhang, X., \& Robinson, S. (2003). Structural change and economic growth in China. Review of Development Economics, 7 (3), 360-377.

Felipe, J., Leon-Ledesma, M., Lanzafame, M., \& Estrada, G. (2007). Sectoral engines of growth in developing Asia: Stylized facts and implication. ERD Working Paper, No. 107.

Felipe, J., \& Mehta, A. (2016). Deindustrialization? A global perspective. Economics Letters, 149, 148-151.

Fingleton, B., \& McCombie, J. (1998). Increasing returns and economic growth: Some new evidence from manufacturing from the European Union regions. Oxford Economic Papers, 50 (1), 89-105.

Fiorillo, F. (2001). Rate of growth and sector specialisation coevolution in a Kaldorian export-led growth model. Structural Change and Economic Dynamics, 12 (1), 91-114.

Fisher, A. G. B. (1939). Production, primary, secondary and tertiary. Economic Record, 15 (1), 24-38.

Frankel, J. (2012). The natural resource curse: A survey of diagnoses and some prescriptions. HKS Faculty Research Working Paper Series, No. RWP12-014. John F. Kennedy School of Government, Harvard University.

Freitas, F. (2003). O Modelo Kaldoriano de crescimento liderado pelas exportações. In Anais do XXXI Encontro Nacional de Economia [Proceedings of the $31^{\text {st }}$ Brazilian Economics Meeting], ANPEC - Associação Nacional dos Centros de Pós-Graduação em Economia [Brazilian Association of Graduate Programs in Economics].

Gill, I. S., Izvorski, I., van Eeghen, W., \& De Rosa D. (2014). Diversified development-Making the most of natural resources in Eurasia. International Bank for Reconstruction and Development \& The World Bank. 
Golodnikova, A. E., Efremov, A. A., Sobol, D. V., Tsygankov, D. B., \& Shklyaruk, M. S. (2018). Regulatory policy in Russia: Main trends and architecture of the future. Moscow: Center for Strategic Research (in Russian).

Gouvea, R. R., \& Lima, G. T. (2010). Structural change, balance-of-payments constraint, and economic growth: Evidence from the multisectoral Thirlwall's law. Journal of Post Keynesian Economics, 33 (1), 169-204.

Gouvea, R., \& Lima, G. (2013). Balance of payments constrained growth in a multisectoral framework: A panel data investigation. Journal of Economic Studies, 40 (2), 240-254.

Greenwood, J., \& Seshadri, A. (2005). Technological progress and economic transformation. In P. Aghion, \& S. Durlauf (Eds.), Handbook of economic growth (vol. 1B, pp. 1225-1273). Amsterdam \& New York: North Holland.

Gurvich, E., \& Prilepskiy, I. (2013). How to secure external sustainability of the Russian economy. Voprosy Ekonomiki, 9, 4-39 (in Russian). https://doi.org/10.32609/0042-8736-2013-9-4-39

Haraguchi, N., Cheng, C. F. C., \& Smeets, E. (2017). The importance of manufacturing in economic development: Has this changed? World Development, 93, 293-315.

Harberger, A. C. (1998). A vision of the growth process. American Economic Review, 88 (1), 1-32.

Harrod, R. (1939). An essay in dynamic theory. Economic Journal, 49 (193), 14-33.

Hausmann, R., Hwang, J., \& Rodrik, D. (2007). What you export matters. Journal of Economic Growth, 12 (1), 1-25.

Hausmann, R., Klinger, B., \& Wagner, R. (2008). Doing growth diagnostics in practice: A "mindbook". CID Working Paper, No. 177.

Hausmann, R., \& Rodrik, D. (2003). Economic development as self-discovery. Journal of Development Economics, 72 (2), 603-633.

Herrendorf, B., Rogerson R., \& Valentinyi, A. (2014). Growth and structural transformation. In P. Aghion, \& S. Durlauf (Eds.), Handbook of economic growth (vol. 2, pp. 855-941). Amsterdam \& New York: North Holland.

Hirschman, A. O. (1958). The strategy of economic development. New Haven, CT: Yale University Press.

Imbs, J., \& Wacziarg, R. (2003). Stages of diversification. The American Economic Review, 93 (1), 63-86.

Imbs, J., Montenegro, C., \& Wacziarg, R. (2014). Economic integration and structural change. Unpublished manuscript. https://www.tse-fr.eu/sites/default/files/medias/stories/sem_12_13/ eco_politique/imbs.pdf

Jackson, W. A. (2003). Social structure in economic theory. Journal of Economic Issues, 37 (3), 727-746.

Jones, B. F., \& Olken, B. A. (2005). The anatomy of start-stop growth. NBER Working Paper, No. 11528.

Kaldor, N. (1978 [1966]). Causes of the slow rate of economic growth in the United Kingdom. In N. Kaldor (Ed.), Further essays on economic theory (pp. 282-310). New York: Holmes \& Meier.

Kondratiev, V. (2017). Reshoring as a form of reindustrialization. World Economy and International Relations, 61 (9), 54-65 (in Russian).

Kruger, J. J. (2008). Productivity and structural change: A review of the literature. Journal of Economic Surveys, 22 (2), 330-363.

Krugman, P. (1989). Differences in income elasticities and trends in real exchange rates. European Economic Review, 33 (5), 1001-1046.

Kuznets, S. (1973). Modern economic growth: Findings and reflections. American Economic Review, 63 (3), 247-258.

Lanzafame, M. (2014). The balance of payments-constrained growth rate and the natural rate of growth: New empirical evidence. Cambridge Journal of Economics, 38 (4), 817-838.

Lewis, W. A. (1954). Economic development with unlimited supplies of labour. The Manchester School, 22 (2), 139-191.

Libanio, G., \& Moro, S. (2011). Manufacturing industry and economic growth in Latin America: A Kaldorian approach. In Anais do XXXVII Encontro Nacional de Economia [Proceedings of the $37^{\text {th }}$ Brazilian Economics Meeting], ANPEC - Associação Nacional dos Centros de Pós-Graduação em Economia [Brazilian Association of Graduate Programs in Economics].

Lin, J. Y. (2011). New structural economics: A framework for rethinking development. The World Bank Research Observer, 26 (2), 193-221. 
Lin, J., \& Chang, H. J. (2009). Should industrial policy in developing countries conform to comparative advantage or defy it? A debate between Justin Lin and Ha-Joon Chang. Development Policy Review, 27 (5), 483-502.

Lin, J. Y., \& Monga, C. (2011). Growth identification and facilitation: The role of state in the process of dynamic growth. Development Policy Review, 29 (3), 264-290.

Lin, J. Y., \& Rosenblatt, D. (2012). Shifting patterns of economic growth and rethinking development. Journal of Economic Policy Reform, 15 (3), 171-194.

Maddison, A. (1987). Growth and slowdown in advanced capitalist economies: Techniques of quantitative assessment. Journal of Economic Literature, 25 (2), 649-698.

Maddison, A. (1991). Dynamic forces in capitalist development: A long-run comparative view. New York: Oxford University Press.

Maroto-Sánchez, A., \& Cuadrado-Roura, J. R. (2009). Is growth of services an obstacle to productivity growth? A comparative analysis. Structural Change and Economic Dynamics, 20, 254-265.

Matsuyama, K. (2009). Structural change in an interdependent world: A global view of manufacturing decline. Journal of the European Economic Association, 7 (2/3), 478-486.

McMillan, M. S., \& Rodrik, D. (2011). Globalization, structural change and productivity growth. NBER Working Papers Series, No. 17143.

McMillan, M., Rodrik, D., \& Sepulveda, C. (2017). Structural change, fundamentals and growth: A framework and case studies. NBER Working Paper, No. 23378.

McMillan, M., Rodrik, D., \& Verduzco-Gallo, H. (2014). Globalization, structural change, and productivity growth, with an update on Africa. World Development, 63, 11-32.

Meliciani, V. (2002). The impact of technological specialisation on national performance in a balance-of-payment-constrained growth model. Structural Change and Economic Dynamics, $13(1), 101-118$.

Mironov, V. (2006). Economic growth and competitiveness in Russia: Price and non-price factors of analysis. Voprosy Ekonomiki, 3, 42-61 (in Russian). https://doi.org/10.32609/0042-87362006-3-42-61

Mironov, V., \& Kanofyev, V. (2014). Impending recession and how to fight it: Empirical analysis of Russian reality and global experience. Voprosy Ekonomiki, 1, 78-107 (in Russian). https:// doi.org/10.32609/0042-8736-2014-1-78-107

Newfarmer, R., Shaw, W., \& Walkenhorst, P. (Eds.) (2009). Breaking into new markets. Emerging lessons for export diversification. Washington, DC: The World Bank.

Nishi, H. (2016). A multi-sectoral balance-of-payments-constrained growth model with sectoral heterogeneity. Structural Change and Economic Dynamics, 39, 31-45.

Nordhaus, W. D. (2015). Are we approaching an economic singularity? Information technology and the future of economic growth. Cowles Foundation Discussion Paper, No. 2021. Yale University.

Ocampo, J. A. (Ed.) (2005). Beyond reforms: Structural dynamics and macroeconomics vulnerability. Palo Alto, CA: Stanford University Press; Washington, DC: World Bank.

Ocampo, J., Rada, C., \& Taylor, L. (2009). Growth and policy in developing countries: A structuralist approach. New York: Columbia University Press.

Oreiro, J. (2016). Inconsistency and over determination in balance of payments constrained growth models: A note. Review of Keynesian Economics, 4 (2), 193-200.

Palley, T. (2003). Pitfalls in the theory of growth: An application to balance-of-payments constrained growth model. Review of Political Economy, 15 (1), 75-84.

Palma, J. G. (1987). Structuralism. In J. Eatwell, M. Milgate, \& P. Newman (Eds.), The New Palgrave: A dictionary of economics (pp. 136-143). London: Macmillan.

Park, D., \& Shin, K. (2012). The service sector in Asia: Is it an engine of growth? ADB Economics Working Paper Series, No. 322.

Pasinetti, L. (1981). Structural change and economic growth-A theoretical essay on the dynamics of the wealth of the nations. Cambridge: Cambridge University Press.

Pasinetti, L. (1993). Structural economic dynamics - A theory of the economic consequences of human learning. Cambridge: Cambridge University Press.

Pieper, U. (2003). Sectoral regularities of productivity growth in developing countries - a Kaldorian interpretation. Cambridge Journal of Economics, 27 (6), 831-850.

Pons-Novell, J., \& Viladecans-Marsal, E. (1999). Kaldor's laws and spatial dependence: Evidence for the European regions. Regional Studies, 33 (5), 443-451. 
Prebisch, R. (2000 [1949]). O desenvolvimento econômico da América Latina e seus principais problemas. In R. Bielschowsky (Ed.), Cinquenta anos de pensamento na CEPAL (vol. 1, pp. 69-136). Rio de Janeiro: Record.

Rodrik, D. (2003). Growth strategies. Cambridge, MA: Kennedy School of Government, Harvard University.

Rodrik, D. (2010). Diagnostics before prescription. Journal of Economic Perspectives, 24 (3), 33-44.

Rodrik, D. (2013a). Structural change, fundamentals and growth: An overview. Institute for Advanced Study, September, revised. http://j.mp/2nyz4as

Rodrik, D. (2013b). The past, present, and future of economic growth. Global Citizen Foundation. Working Paper, No. 1.

Rodrik, D. (2013c). Unconditional convergence in manufacturing. Quarterly Journal of Economics, $128(1), 165-204$.

Rodrik, D. (2015). Premature deindustrialization. NBER Working Paper, No. 20935.

Romano, L., \& Trau, F. (2017). The nature of industrial development and the speed of structural change. Structural Change and Economic Dynamics, 42, 26-37.

Romero, J., \& McCombie, J. (2016). The multi-sectoral Thirlwall's law: Evidence from 14 developed European countries using product level data. International Review of Applies Economics, 30 (3), 301-332.

Setterfield, M. (2011). The remarkable durability of Thirlwall's law. PSL Quarterly Review, 64 (259), 393-427.

Silva, E. G., \& Teixeira, A. A. C. (2008). Surveying structural change: Seminal contributions and a bibliometric account. Structural Change and Economic Dynamics, 19, 273-300.

Schumpeter, J. (1962). Capitalism, socialism and democracy ( $3^{\text {rd }}$ ed). New York: Harper Torchbooks.

Solow, R. M. (1956). A contribution to the theory of economic growth. Quarterly Journal of Economics, 70, 65-94.

Soukiazis, E., \& Cerqueira, P. A. (Eds.) (2012). Models of balance of payments constrained growth: History, theory and empirical evidence. Basingstoke, UK: Palgrave Macmillan.

Swan, T. W. (1956). Economic growth and capital accumulation. Economic Record, 32, 334-361.

Szirmai, A. (2012). Proximate, intermediate and ultimate causality: Theories and experiences of growth and development. UNU-MERIT Working Paper Series, No. 032.

Thirlwall, A. (1979). The balance of payments constraint as an explanation of international growth rate differences. BNL Quarterly Review, 32 (128), 45-53.

Thirlwall, A. P. (2011). Balance of payments constrained growth models: History and overview. Paper prepared for the Workshop on "Thirlwall's law and balance of payments constrained growth," University of Coimbra, 24-25 June.

Thirlwall, A. P. (2013). Economic growth in an open developing economy: The role of structure and demand. Cheltenham: Edward Elgar.

Timmer, M. P., \& de Vries, G. J. (2009). Structural change and growth accelerations in Asia and Latin America: A new sectoral data set. Cliometrica, 3 (2), 165-190.

Timmer, M. P., Dietzenbacher, E., Los, B., Stehrer, R., \& de Vries G. J. (2015a). An illustrated user guide to the world input-output database: The case of global automotive production. Review of International Economics, 23, 575-605.

Timmer, M. P., de Vries, G. J., \& de Vries, K. (2015b). Patterns of structural change in developing countries. In J. Weiss, \& M. Tribe (Eds.), Routledge handbook of industry and development (pp. 65-83). Routledge.

UNIDO (2016). Industrial development report. The role of technology and innovation in inclusive and sustainable industrial development. Vienna: UNIDO.

Uzawa, H. (1961). On a two-sector model of economic growth. Review of Economic Studies, 29 (1), 40-47.

Voskoboynikov, I., \& Gimpelson, V. (2015). Productivity growth, structural change and informality: The case of Russia. Voprosy Ekonomiki, 11, 30-61 (in Russian). https://doi.org/10.32609/00428736-2015-11-30-61

$\mathrm{Vu}, \mathrm{K}$. M. (2017). Structural change and economic growth: Empirical evidence and policy insights from Asian economies. Structural Change and Economic Dynamics, 41, 64-77.

Wells, H., \& Thirlwall, A. P. (2003). Testing Kaldor's growth laws across the countries of Africa. African Development Review, 15 (2-3), 89-105. 